\title{
Fruit (pericarp and seed) ontogeny of Sida species
}

\section{Ontogenia del fruto (pericarpio y semilla) de especies de Sida}

\author{
Junior C. MuneratTo \& LUiz A. Souza* \\ Departamento de Biologia, Centro de Ciências Biológicas, Universidade Estadual de Maringá, Avenida Colombo, 5790 \\ (87020-900) Maringá, Paraná, Brasil. \\ *lasouza@uem.br
}

\begin{abstract}
Fruits (pericarps and seeds) of the weedy species Sida rhombifolia L., S. urens L. and S. regnellii R. E. Fr. were analyzed structurally using light and scanning electron microscopy. The yellowish brown calyx is persistent on the mature fruit and consists of a crystalliferous hypodermis with U-shaped wall thickenings and homogeneous mesophyll. Fruits are schizocarpic, of the subtype coccarium, with a fibrous endocarp. Seeds are exotegmic and the embryos are clearly bent, with folded cotyledons. Structural features that are potentially significant to species' characterization are the structure of the ovary, the morphology of the mericarp apex, the pattern of the reticulate sclerenchymatous endocarp and the presence or absence of nonglandular trichomes in the hilum and funiculus of the seed.
\end{abstract}

KEYwORDs: Pericarp, seed, Malvaceae, weedy species, ovary.

\section{RESUMEN}

Los frutos (pericarpios y semillas) de las especies dañinas Sida rhombifolia L., S. urens L. y S. regnellii R. E. Fr. fueron analizados estructuralmente usando microscopio de luz y microscopio electrónico. El cáliz castaño amarillento es persistente en el fruto maduro y consta de una hipodermis cristalífera con engrosamientos en U de la pared y mesófilo homogéneo. Los frutos son esquizocarpos del subtipo coccarium, con un endocarpo fibroso. Las semillas son exotégmicas y los embriones curvos, con los cotiledones plegados. Las características estructurales que son potencialmente significativas para la caracterización de las especies son la estructura del ovario, la morfología del ápice del mericarpo, el patrón esclerenquimatoso reticulado del endocarpo y la presencia o ausencia de tricomas tectores en el hilo y el funículo de la semilla.

Palabras clave: Pericarpio, semilla, Malvaceae, especies dañinas, ovario.

\section{INTRODUCTION}

Sida L. includes shrubs or herbs that compete with crop plants for water, light and nutrients. This genus comprises 200 species with a worldwide distribution, though preferring warmer regions (Willis 1973).

Many weedy species of Sida compete with crop plants and produce a large quantity of viable seeds in a single growing season. Like this, three weeds, S. regnellii R. E. Fr. (Sect. Cordifoliae), Sida rhombifolia L. (Sect. Sidae) and $S$. urens L. (Sect. Nelavagae), were selected because they have ability to rapidly establish in Brazilian cropping system.

The literature records several types of fruits for Malvaceae. Schizocarpic fruits (of the achenarium, camarium, coccarium and druparium subtypes) and loculicidal capsules are described by Spjut (1994). Barroso et al. (1999) considered the schizocarpic, loculicidal capsules and bacoid fruits for the family. According to Judd et al. (2002), the following fruit types are found within the family: loculicidal capsule, schizocarp, nut, indehiscent pod, aggregate of follicles, drupe and berry. While there is general agreement on the overall characteristics of the schizocarp fruit in Sida, there is disagreement on subtype structural features. For instance, according to Spjut (1994) the genus Sida presents schizocarp subtype Camarium and Barroso et al. (1999) register the "Coca" or "Mericarpo".

Malvaceae seeds appear to have an uniform structure, of which the main characteristic is the exotegmen palisade (Corner 1976).

Although the Sida species have been well-studied given their importance, relatively little attention has been paid to the anatomy of their fruits and seeds. There have been some 
studies published on the seeds of $S$. cordifolia L. and $S$. veronicaefolia (Rao 1955) and the histo-architecture of the pericarp and seed of Sida rhombifolia (Rao \& Dave 2006).

The purpose of this investigation was to present a detailed comparative description of the fruit (pericarp) and seed development in the three Sida species, emphasizing the following aspects: a) an indication of the structural characters that can be useful in the identification of the species; and b) characterization of the structural subtype of schizocarp in Sida spp.

\section{MATERIAL AND METHODS}

The study material (flowers, developing fruits and seeds) was collected at Maringá city, in Brazil (state of Paraná), at the following coordinates: altitude $506 \mathrm{~m}$, latitude $23^{\circ}$ 24' 13.3 " and longitude $51^{\circ} 56^{\prime} 21.17$ ', for S. rhombifolia; altitude $559 \mathrm{~m}$, latitude $23^{\circ} 24^{\prime} 43.0^{\prime \prime}$ and longitude $51^{\circ} 56^{\prime}$ $29.6^{\prime \prime}$, for S. regnellii; and altitude $518 \mathrm{~m}$, latitude $23^{\circ} 24^{\prime}$ $13.1^{\prime \prime}$ and longitude $51^{\circ} 56^{\prime} 20.4^{\prime \prime}$, for S. urens. Voucher materials were deposited at the Universidade Estadual de Maringa (UEM) Herbarium, and given the collection numbers: S. rhombifolia 19910; S. regnellii 19911; and $S$. urens 19909.

Anatomical studies were performed on material that had been fixed in glutaraldehyde $(1 \%$ in $0.1 \mathrm{M}$ phosphate buffer, pH 7.2) (Karnovsky 1965) and then preserved in $70 \%$ ethanol. The fixed material was embedded in historesin (Guerrits 1991), sectioned (cross- and longitudinal sections) in a rotation microtome, and stained with toluidine blue (O’Brien et al. 1964).

Specific microchemical tests were carried out for lipid substances (using Sudan IV and Sudam Black dyes) (Ruzin 1999), starch (iodine-potassium iodide test), lignin (phloroglucin test) (Berlyn \& Miksche 1976), tannin (ferric chloride) and calcium crystals (sulphuric acid) (Sass 1951).

Anatomical illustrations were prepared using Leica ICC50 and Olympus BX50 optical microscopes with a digital camera. All samples were prepared on the same micrometric scale.

Micromorphological analysis of the fruits and seeds was undertaken on material fixed in a Karnovsky solution (Karnovsky 1965). Samples were processed and then mounted on aluminum stubbs, gold-coated, and subsequently examined using scanning electron microscopy (Shimadzu SS-550 Superscan), obtaining digital images.

\section{RESULTS}

\section{DEVELOPING PERICARP}

The globose ovary (Fig. 1a) was found to consist of nine or ten carpels in $S$. rhombifolia and five carpels in each of $S$. regnellii and $S$. urens. An inward folding was apparent in the superior and median portions of each carpel (Fig. 1a,b). The trichomes were restricted to the superior portion of the ovary (Fig. 1b). There was a striking distinction between the trichomes of the species, which in S. rhombifolia were found to be eglandular, fasciculate and stellate, and glandular capitate; in $S$. regnellii eglandular, simple and ramified; and in the $S$. urens the trichomes were only eglandular and simple.

The ovary wall (Fig. 1c) consisted of a uniseriate outer epidermis, a parenchymatous mesophyll with a crystalliferous hypodermis and several mucilaginous cells, and an inner epidermis. This inner epidermis had become either bilayered (Fig. 1c) or multilayered by cell divisions in planes parallel to the inner surface, which were still in the pre-anthesis stage. The ovary septum (Fig. 1d) consisted of bi- or multiseriate epidermis and parenchyma with mucilaginous and druse cells. Vascularization of each carpel was made by a median dorsal bundle, one or two lateral bundles, and a ventral or placental bundle.

The calyx (Fig. 2a) persisted on the developing fruit with a 1-layered epidermis consisting of stomata and trichomes. The adaxial (inner) epidermis was devoid of stomata, but possessed unicellular nonglandular trichomes; and the outer periclinal wall of the cells was thicker than other cell walls. Stomata occurred on the abaxial (outer) epidermis and the trichomes were nonglandular (unicellular, fasciculate and stellate) and glandular (multicellular). Below the inner epidermis is a crystalliferous hypodermis cells layer with U-shaped wall thickenings. The mesophyll had spongy parenchyma with mucilaginous cells and cavities.

In the developing fruit, the exocarp (Fig. 2b,c) had the same appearance as that on the ovary's epidermis. The mesocarp consisted of parenchyma (Fig. 2b), the innermost layers being more or less collapsed; druses were common, particularly in the adaxial layer. The endocarp was composed of either a single layer, or multilayered (Fig. 2b,c). The endocarpic cells were found to undergo subsequent differentiation by cellular elongation. The septum (Fig. 2c) between the adjacent carpels had elongated endocarp cells, while the cells of the middle layer were compressed and tangentially elongated.

The yellowish brown calyx was persistent on the mature fruit (Fig. 3b,d,f) and had a very similar structure to the calyx of the developing fruit and ovary. The fruit was subglobose in S. rhombifolia and globose in S. regnellii and $S$. urens. It was a schizocarpic fruit that divided into its carpellary constituents (mericarps): nine to eleven mericarps in $S$. rhombifolia in contrast to the five mericarps exhibited by the other two species (Fig. 3a-f). The mericarp apex differed between the three species: the $S$. rhombifolia mericarp had two short spines (Fig. 4a,b) while $S$. regnellii had two long ones (Fig. 4c,d); in contrast, S. urens' mericarp was muticous (Fig. 4e,f). There was fundamental difference 
found between the surfaces of the ovary and the mature fruit; that is, glandular trichomes were shed in dry fruits and reticulate endocarp was evident in the dorsal and/or ventral faces of the mericarps (Fig. 4g,h).

When fruit reached maturity, the exocarp developed tangentially elongated cells (Fig. 5a,d), and trichomes were observed in the fruit apex (Fig. 5c). Sida rhombifolia trichomes were stellate and fasciculate with three to five units. Both unbranched and two- or three-armed unicellular trichomes occurred in S. regnellii. On the other hand, S. urens presented unicellular trichomes (Fig. 5c), gradually narrowing to a sharp point in which its base was surrounded by a ring of epidermal cells. The mature mesocarp was parenchymatous (Fig. 5a,b,d) with collapsed cells becoming crushed in $S$. urens. Mucilaginous cells were possibly present in the mesocarp, and druses were found, especially in the outermost layer. The ripe endocarp
(Fig. 5a,b,d) consisted of epidermal cells with thin walls and thick-walled fibers. The fibrous endocarp was one to several cell-layers thick (Fig. 5a,b,d). There was an anastomosing network of fibers in the endocarp running through the pericarp (occupying two-thirds of the fruit) (Fig. 4). The fibers were concentrated on the proximities of the vascular bundle and septum (Fig. 5b,d).

Each septum (Fig. 5e,f) consisted of an epidermal and fibrous endocarp which was either unilayered or multilayered, and parenchyma. The middle region of this parenchyma contained crystals and consisted of approximately spherical cells with intercellular spaces between them, forming a separation layer. Marginal or ventral bundles occurred in the center of the ovary (Fig. 5g), as well as mucilaginous cells and a variable amount of surrounding non-vascular tissue with intercellular spaces: these were conspicuous in S. urens (Fig. 5h).

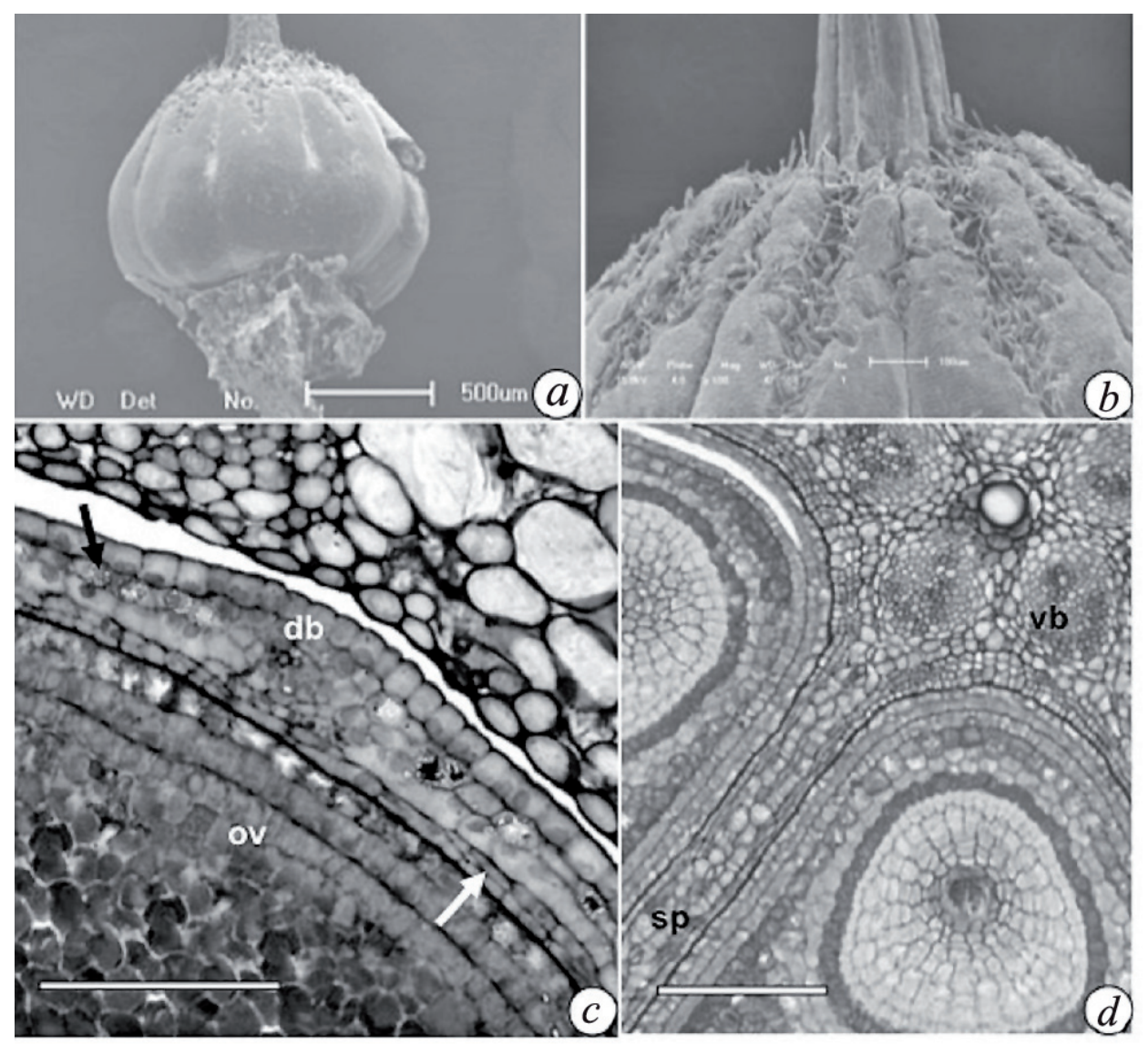

Figure 1. Ovary structure in Sida species. $(a, b)$ S. rhombifolia. (c) S. urens. (d) S. regnellii. $(a, b)$ Ovary under scanning electron microscopy (SEM). (c,d) Ovary in cross-section, evidencing hypodermis (black arrow), inner epidermis in division (white arrow), dorsal bundle (db), ovule (ov), septum (sp) and ventral bundle (vb). Scale bars: $500 \mu \mathrm{m}(a), 100 \mu \mathrm{m}(b, c, d)$.

Figura 1. Estructura del ovario en especies de Sida. (a,b) S. rhombifolia. (c) S. urens. (d) S. regnellii. (a,b) Ovario visto en microscopio electrónico. $(c, d)$ Ovario en corte transversal evidenciando la hipodermis (flecha negra), epidermis interna en división (fecha blanca), luz dorsal (db), óvulo (ov), septo (sp) y luz ventral (vb). Barras: $500 \mu \mathrm{m}(a), 100 \mu \mathrm{m}(b, c, d)$. 



Figure 2. Calyx and immature fruit in Sida species. (a,b) S. regnellii. (c) S. rhombifolia. (a) Sepal in cross-section evidencing hypodermis (head black arrow), trichome and stomata (black arrow). (b,c) Fruits in longitudinal section showing endocarp (en), exocarp (ex), septum (sp) and young seed (ys). Scale bar: $100 \mu \mathrm{m}$.

Figura 2. Cáliz y fruto inmaduro en especies de Sida. $(a, b)$ S. regnellii. (c) S. rhombifolia. (a) Sépalo en corte transversal evidenciando la hipodermis (cabeza de flecha negra), tricoma y estoma (flecha negra). ( $b, c)$ Frutos en corte longitudinal que muestran endocarpo (en), exocarpo (ex), septo (sp) y semilla joven (ys). Barra: $100 \mu \mathrm{m}$. 

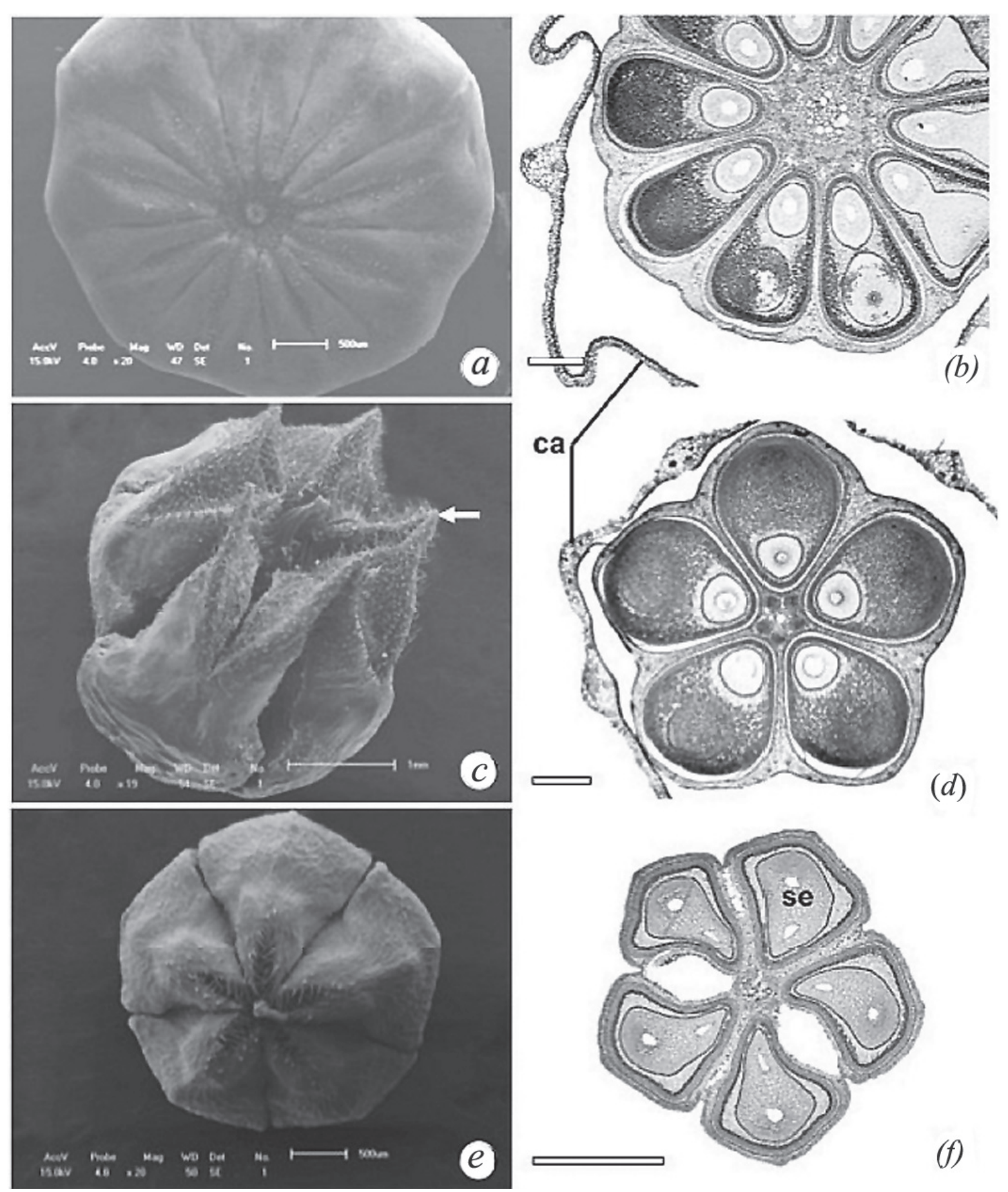

FiguRE 3. Morphology of the mature fruit in Sida species. $(a, b) S$. rhombifolia. $(c, d)$ S. regnellii. $(e, f)$ S. urens. (a,c,e) Fruits under scanning electron microscopy (SEM) (white arrow indicates spine). ( $b, d, f)$ Fruits in cross-section, showing calyx (ca), carpels, septum and seeds (se). Scale bar: $250 \mu \mathrm{m}$.

Figura 3. Morfología del fruto maduro en especies de Sida. $(a, b) S$. rhombifolia. $(c, d)$ S. regnellii. (e,f) S. urens. (a,c,e) Frutos vistos en microscopio electrónico (flecha blanca muestra espina). ( $b, d, f)$ Frutos en cortes transversales muestran cáliz (ca), carpelos, septo y semillas (se). Barra: $250 \mu \mathrm{m}$. 

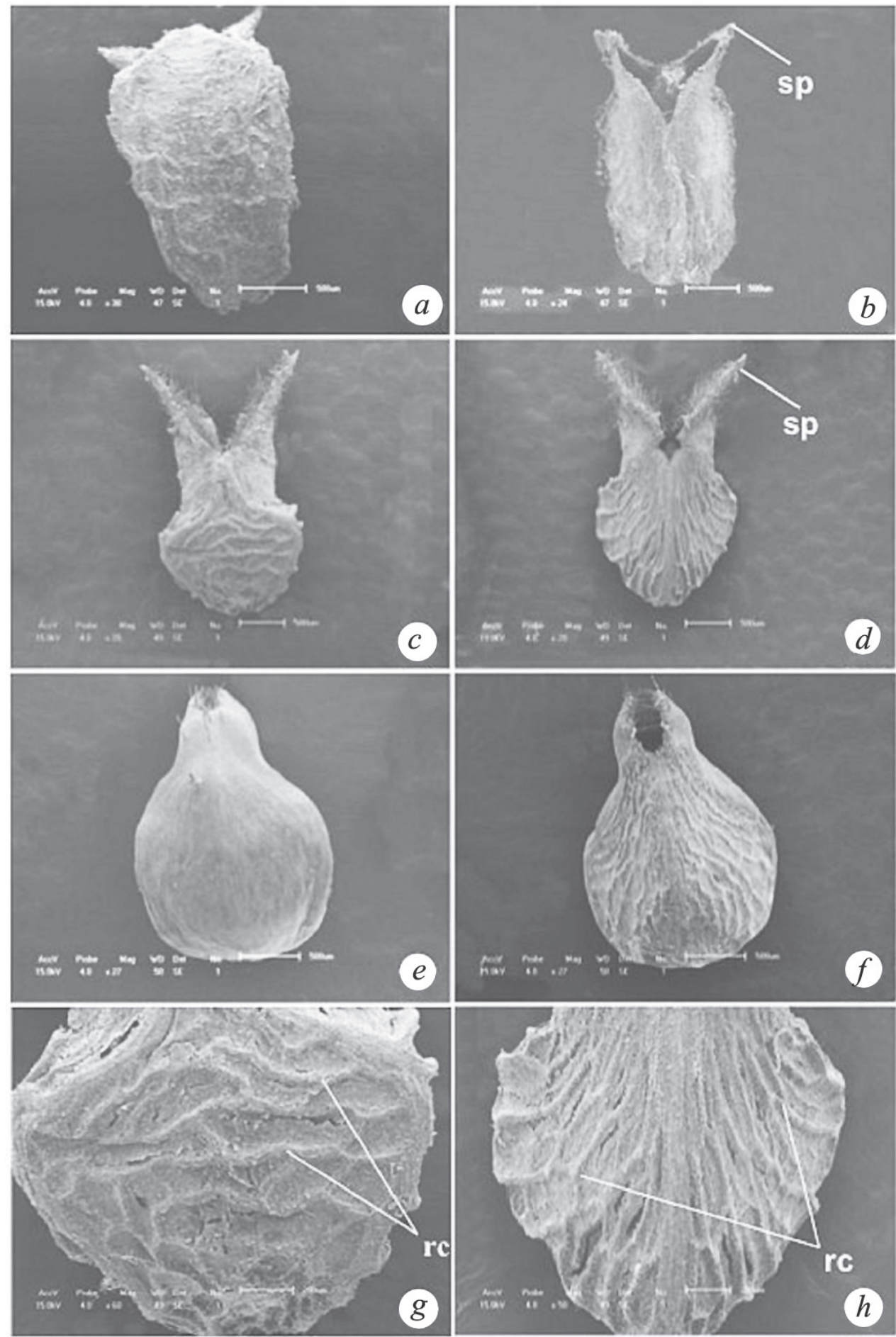

Figure 4. Mericarps in Sida species under scanning electron microscopy (SEM). (a,b) S. rhombifolia. (c,d,g,h) S. regnellii. (e,f) S. urens. Ventral face (a,c,e,g) and dorsal face (b,d,f,h) of the mericarps, evidencing spines (sp) and reticulate endocarp (rc). Scale bars: $200 \mu \mathrm{m}(\mathrm{g}, h)$, $500 \mu \mathrm{m}(a-f)$.

Figura 4. Micrografías electrónicas de los mericarpos de Sida. $(a, b)$ S. rhombifolia. $(c, d, g, h)$ S. regnellii. (e,f) S. urens. cara ventral (a,c,e,g) y cara dorsal (b,d,f,h) de los mericarpos evidenciando espinas (sp) y endocarpo reticulado (rc). Barras: $200 \mu \mathrm{m}(\mathrm{g}, h), 500 \mu \mathrm{m}(a-f)$. 


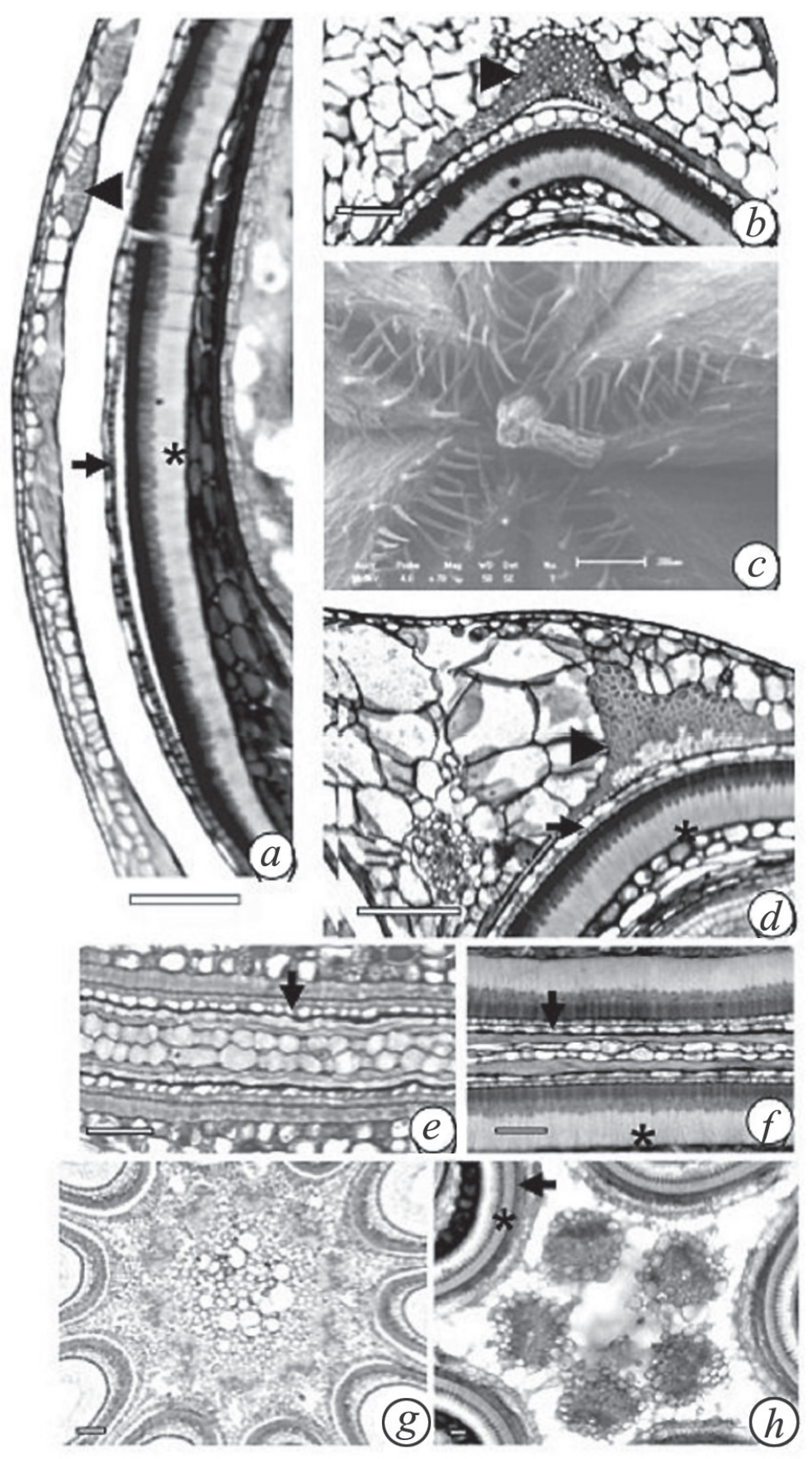

Figure 5. Mature fruit (pericarp) in Sida species. (a) S. regnellii. (b,d,e,f,g) S. rhombifolia. $(c, h)$ S. urens. $(a, b, d)$ Pericarp and seed in longitudinal and cross-section. (c) Fruit apex with trichomes under scanning electron microscopy (SEM). (e,f) Septum and seed-coat in cross-section. $(g, h)$ Central region of the fruit in cross-section. Arrow head, arrow and asterisk indicate endocarp, testa and exotegmen, respectively. Scale bars: $50 \mu \mathrm{m}(e-h), 100 \mu \mathrm{m}(a, b, d), 200 \mu \mathrm{m}(c)$.

Figura 5. Fruto maduro (pericarpio) en especies de Sida. (a) S. regnellii. (b,d,e,f,g) S. rhombifolia. (c,h) S. urens. (a,b,d) Pericarpio y semilla en corte longitudinal y transversal. (c) Micrografias electrónicas del ápice del fruto con tricomas. (e,f) Septo y tegumento de la semilla en corte transversal. $(g, h)$ Región central del fruto en corte transversal. Cabeza de flecha, flecha y asterisco indican endocarpo, testa y exotegmen, respectivamente. Barras: $50 \mu \mathrm{m}(e-h), 100 \mu \mathrm{m}(a, b, d), 200 \mu \mathrm{m}(c)$. 
In the fruit, dehiscence involved the separation tissue and endocarpic sclerenchyma. Separation tissue was found in the middle region of each septum (Fig. 5f), and in the apex and dorsal region of the fruit. The dehiscence initially occurred among carpels separating the mericarps, and each mericarp dehisced in the median (dorsal) and upper plane (Fig. 3c).

\section{DEVELOPING SEED}

The seed originated from the campylotropous, bitegmic and crassinucellate ovules. The ovule has a short funiculus, and both the integuments took part in the formation of the micropyle, with the micropylar canal (exostome and endostome) forming a zigzag outline. The outer integument was two-layered (Fig. 6a) and either three- or four-layered in the micropylar region. The inner integument (Fig. 6a) consisted of three to ten layers. Cells of both the integuments were cuboid, columnar or tangentially elongated. Phenolic substances occurred usually in the epidermis of the inner integument (Fig. 6a), chalaza and funiculus cells. The nucellus was formed of thin-walled cells (Fig. 6a). The vascular supply consisted of a single collateral bundle extending to the chalaza.

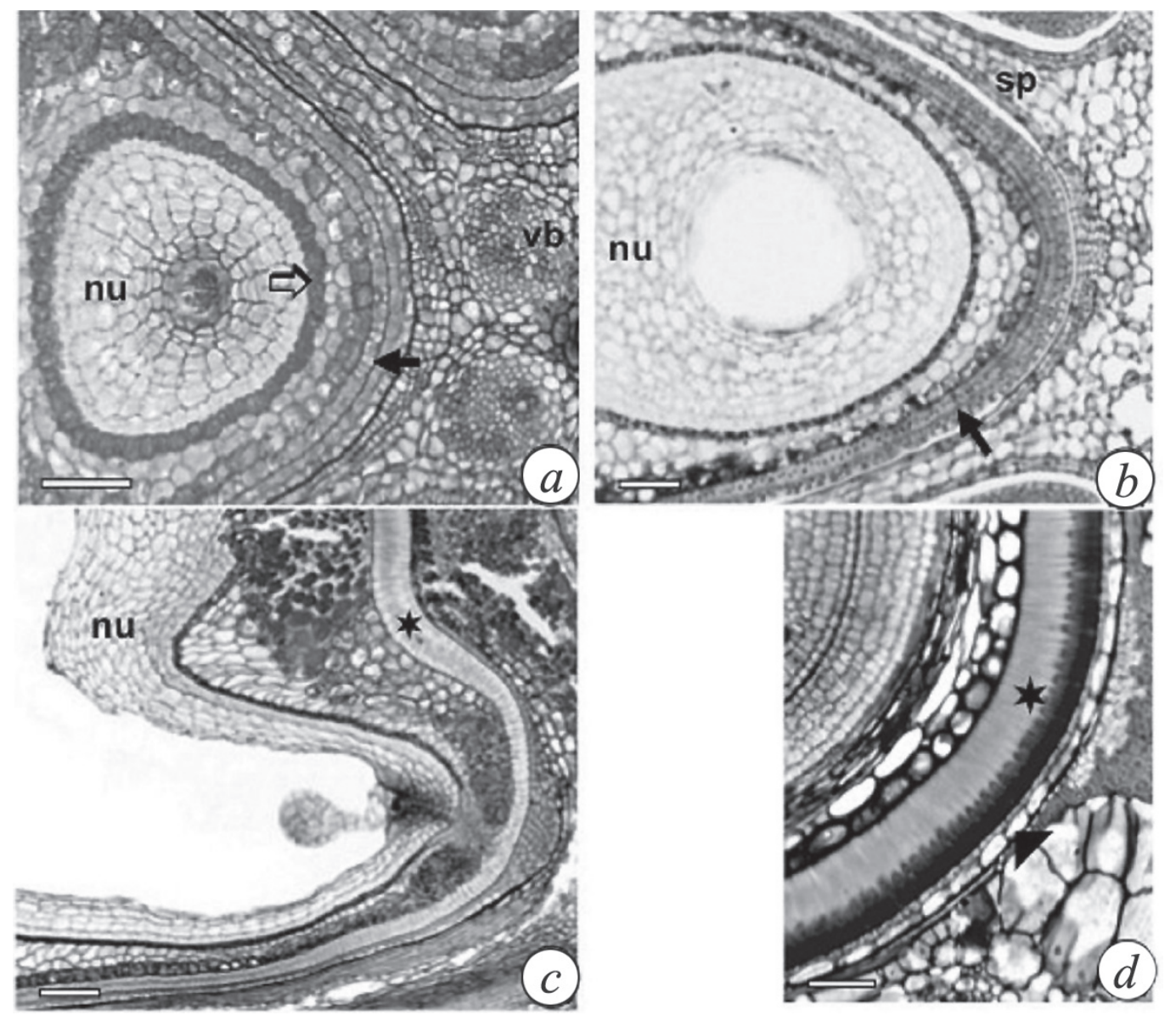

Figure 6. Development of the seed in Sida species. (a,c) S. regnellii. (b,d) S. rhombifolia. (a) Ovary and ovule in cross-section showing septum, ventral vascular bundles (vb), outer and inner integuments (black arrow indicates the limit among the integuments), nucellus (nu) and inner epidermis of the inner integument (white arrow). (b,c) Young pericarp and seed in cross-section and longitudinal section evidencing septum (sp), nucellus (nu), the limit among the testa and tegmen (black arrow), and immature macrosclereids (asterisk). (d) Adult seed in cross-section with biseriate testa (arrow head) and tegmen (asterisk indicates exotegmen). Scale bar: $50 \mu \mathrm{m}$.

Figura 6. Desarrollo de la semilla en especies de Sida. $(a, c)$ S. regnellii. $(b, d)$ S. rhombifolia. (a) Ovario y óvulo en corte transversal que muestran septo, haces vasculares ventrales, tegumentos externo e interno (la flecha negra indica el límite entre los tegumentos), nucelo (nu) y epidermis interna del tegumento interno (flecha blanca). $(b, c)$ Pericarpio joven y semilla en corte transversal y longitudinal que evidencian el septo (sp), nucelo (nu), el límite entre la testa y tegumento (flecha negra) y macroesclereidas inmaduras (asterisco). (d) Semilla adulta en corte transversal con la testa biseriada (cabeza de flecha) y tegumento (asterisco indica el exotegumento). Barra: $50 \mu \mathrm{m}$. 

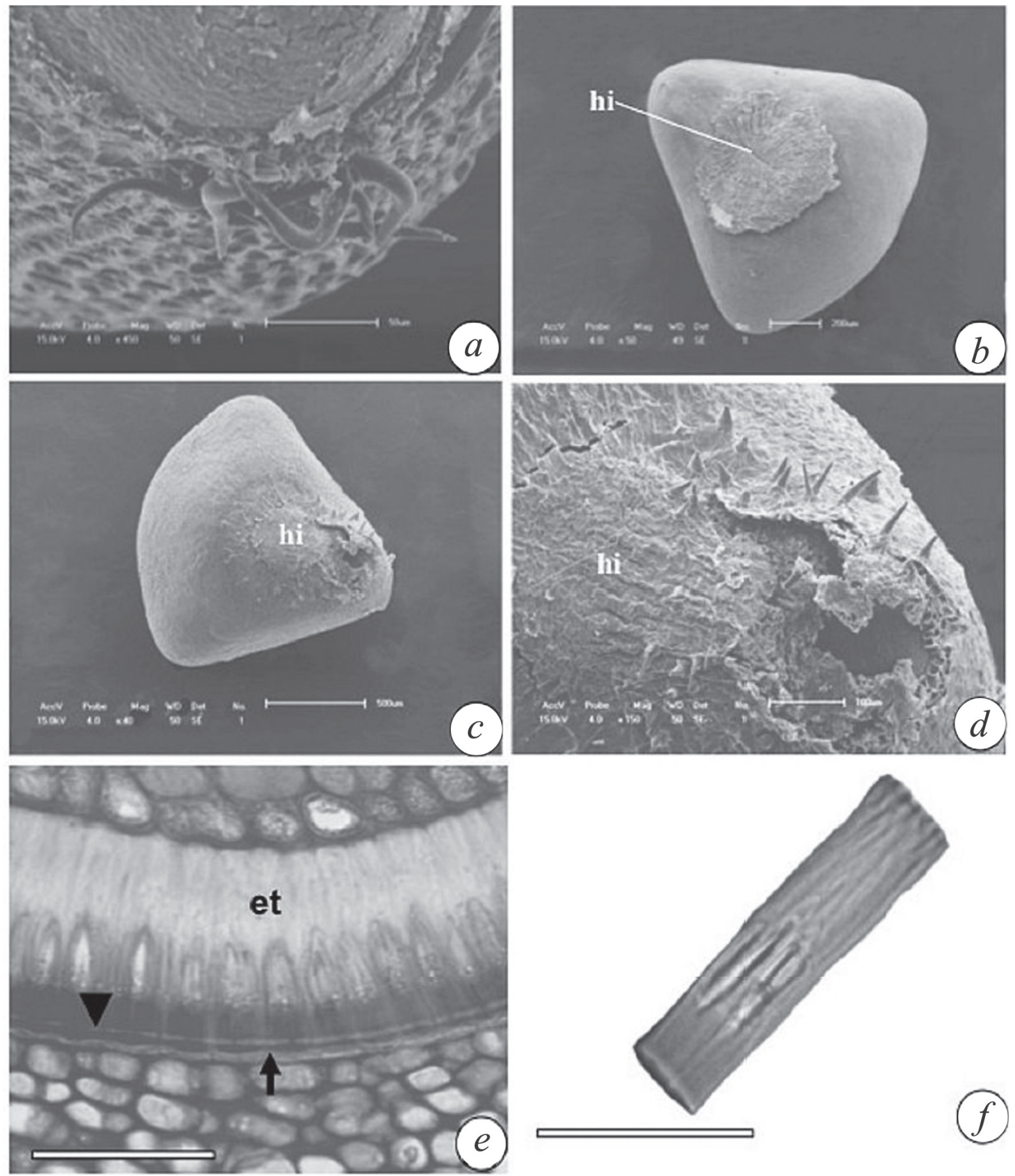

Figure 7. Structure of the mature seed in Sida species. (b) S. regnellii. (a,e,f) S. rhombifolia. (c,d) S. urens. (a-d) Figures under scanning electron microscopy (SEM). $(a, d)$ Nonglandular trichomes in the hilum. $(b, c)$ Cuneiform seeds showing the hilum region. (e) Seed-coat in cross-section evidencing collapsed testa (black arrow), exotegmen macrosclereids (et) and linea lucida (arrow head). $(f)$ Macrosclereid. Scale bars: $50 \mu \mathrm{m}$ (a,e,f), $100 \mu \mathrm{m}(\mathrm{d}), 200 \mu \mathrm{m}(\mathrm{b}), 500 \mu \mathrm{m}$ (c).

Figura 7. Estructura de la semilla madura en las especies de Sida. (b) S. regnellii. $(a, e, f)$ S. rhombifolia. (c,d) S. urens. (a-d) Micrografias electrónicas. $(a, d)$ Tricomas tectores en el hilo. $(b, c)$ Semillas cuneiformes que muestran la región del hilo. $(e)$ Cubierta seminal que evidencia la testa colapsada (flecha negra), macroesclereidas del exotegmen (et) y línea lúcida (cabeza de flecha). (f) Macroesclereida. Barras: $50 \mu \mathrm{m}(\mathrm{a}, \mathrm{e}, \mathrm{f}), 100 \mu \mathrm{m}(\mathrm{d}), 200 \mu \mathrm{m}$ (b), $500 \mu \mathrm{m}$ (c). 



Figure 8. Structure of the embryo in Sida species. $(a, b)$ S. rhombifolia. $(c, d)$ S. regnellii. $(e, f)$ S. urens. $(a, c, e)$ Embryos under scanning electron microscopy (SEM) evidencing cotyledons (co) and hypocotyl-root axis (hr). $(b, d, f)$ Longitudinal sections of cotyledons with druses (black arrow), cotyledon node and plumule, and root apex, respectively. Scale bars: $100 \mu \mathrm{m}(b, d, f), 200 \mu \mathrm{m}(e), 500 \mu \mathrm{m}(a, c)$.

Figura 8. Estructura del embrión en las especies de Sida. $(a, b)$ S. rhombifolia. $(c, d)$ S. regnellii. $(e, f)$ S. urens. $(a, c, e)$ Embriones vistos en microscopio electrónico que evidencian los cotiledones (co) y eje raíz-hipocótilo (hr). ( $b, d, f)$ Cortes longitudinales de los cotiledones con drusas (flecha negra), nudo cotiledonar y plúmula, y ápice de la raíz, respectivamente. Barras: $100 \mu \mathrm{m}(b, d, f), 200 \mu \mathrm{m}(e), 500 \mu \mathrm{m}(a, c)$. 
Immature seed exhibited an outer integument that was not multiplicative (Fig. 6b,c,d) with reduced structural alterations. Exotesta cells underwent tangential elongation and nonglandular trichomes developed both on the funiculus and in the proximity of the hilum of $S$. rhombifolia and $S$. urens. The greatest change occurred in the tegmen in which the cells of the exotegmen showed a radial elongation and the cell wall was already somewhat thickened (Fig. 6d), taking place initially in the hilum region (Fig. 6c). The parenchymatous mesotegmen and endotegmen (Fig. 6b,c,d) were gradually collapsed. The endosperm was nuclear and persistent, but was reduced at maturity.

Mature seed (Fig. 7b,c) was cuneiform, dark brown in color with a more or less circular hilum. Nonglandular trichomes were present in the hilum and funiculus, being fasciculate with two units and stellate in S. rhombifolia (Fig. 7a); and unicellular and simple in S. urens (Fig. 7d); trichomes are entirely lacking in $S$. regnellii seed (Fig. 7b). It was exotegmic, with the outer epidermis forming a palisade of macrosclereids with linea lucida (Fig. 7e). Macrosclereids (Fig. 7f) were strongly thickened, especially in the base and apex of each cell, and contained phenolic substances in the cellular apex. Mesotegmen and endotegmen became more or less crushed. Exotesta was collapsed in some regions of the seed (Fig. 7e) and became multilayered in the hilum. Endotesta were crushed (Fig. 7e) or persistent, varying from a cuboid structure to a layer of tangentially elongated cells. Endosperm was reduced and contained starch.

The embryo was curved with folded cotyledons, a long hypocotyl-root axis and plumule without leaf primordial (Fig. 8). Cotyledons (Fig. 8b) were dorsiventral with palisade parenchyma arranged in one row and spongy parenchyma in three rows of cells; in the mesophyll druse there were idioblasts, together with differentiated vascular bundles and procambial bundles. Glandular trichomes could be seen in the cotyledonary axil region of $S$. urens.

\section{DISCUSSION}

The persistent calyx on the fruit of Sida species can obviously develop different functions. It acted both as a photosynthetic organ during fruit growth and as a protective organ. This latter function of the Sida calyx was related to the presence of thick-walled epidermal cells and crystalliferous hypodermis cells with U-shaped wall thickenings. The functions of the persistent calyx are discussed thoroughly by Roth (1977): not infrequently, it takes on a functions of protection, photosynthesis and dispersion of seed and fruit.

Fruits of Sida were divided into its mericarps, which dehisce partially and dorsiventrally. There is no agreement in the literature on the schizocarp subtypes that occur in the Malvaceae. According to Spjut (1994), within the Malvaceae there is considerable variation between subtypes of fruits: achenarium, camarium, coccarium and druparium. The coca or mericarp of the Malvaceae is described as a schizocarpic, subtype fruit; it is characterized by a variable shape, and is either monospermous or oligospermous, or, uncommonly, polyspermous (Barroso et al. 1999). Based on the fruit characteristics described by Spjut (1994), the schizocarps of $S$. rhombifolia, S. regnellii and S. urens should be considered as a coccarium subtype - "fruitlets opening along their ventral sutures and sometimes the dorsal sutures as a result of their separation from one another or from a central axis".

The definition of exo-, meso- and endocarp can be adopted either in a strict sense ("sensu stricto") or a wide sense ("sensu lato") (Roth 1977). This definition varies, however, according to the viewpoints of the author. A "sensu stricto" definition is established for the Sida fruits, in which the exocarp, mesocarp and endocarp originate respectively from the outer epidermis, mesophyll and inner epidermis of the ovary. The strict definition, based on the pericarp ontogenesis, standardizes the comparative study of fruits.

In pre-anthesis, periclinal and anticlinal divisions are recorded in the inner epidermis of the ovary in Sida. A review of the literature reveals that this ventral or adaxial meristem also takes place in other dry fruits, as legumes, follicles, capsules and schizocarps (Roth 1977, Souza et al. 2005, 2006). Rao \& Dave (2006) recorded cell divisions occurring in the inner epidermis during the course of schizocarp development in S. rhombifolia, but the study was undertaken without any reference to the developmental phase and the concept of adaxial meristem in dry fruits.

The present study revealed that the Sida endocarp consists of fibers and thin-walled epidermal cells. Rao \& Dave (2006) also described the endocarp just consisting of fibers in Sida rhombifolia fruit. The main function of the sclerenchyma is as supporting tissue, to protect the seed from injuries and to take part in the dehiscence process of the fruit (Roth 1977, Souza 2006).

The schizocarp dehiscence of the Sida species involved separation along sutures between carpel walls, separation close to the central column and rupture of the carpel wall itself (dorsal region). Each mericarp was shown to dehisce incompletely along its ventral and dorsal sutures; however, this opening was not enough for the liberation of the seed. The occurrence of mericarps that also separate from each other and also the central of the fruit was registered in other species of Malvaceae (Rao et al. 1986, 1993). The dehiscence of dry fruits is complex, and the separation tissue may be accompanied by a tissue of resistance in the form of a thick-walled lignified sclerenchyma or collenchyma which acts as antagonistic tissue and facilitates fruit dehiscence (Roth 1977, Souza 2006). The anatomical structure of the pericarp of nearly 100 species belonging to over 50 genera of the Leguminosae has been examined by Fahn \& Zohary (1955). According to these authors, 
a close correlation has been found between the mode of dehiscence of the legume, the orientation of the fibers and the micellar structure of the walls. These structural factors should be present in other fruits, as follicles, capsules and schizocarps (Roth 1977, Souza 2006). It is probable that these same factors exercise an influence on the dehiscence of Sida fruits, due to the presence of a separation tissue and reticulate sclerenchymatous endocarp.

The detailed structural features of the endocarp and awnlike apices reveal that the Sida fruits exhibit morphological differences (Krapovickas 2006). The data generated from the Krapovickas (2006) study and the structural analysis of the Sida fruits, especially the reticulate endocarp and apex projections, also may be useful for systematic purposes. As in Sida, the aristate mericarps occur in Pavonia Cav., a genus of Malvaceae, and have revealed diagnostic characters useful in separating the infrageneric taxa (Esteves 2004).

The seed ontogeny of Sida follows the basic structural pattern of Malvaceae species (Corner 1976), including the origin of the ovule, testa not being multiplicative and more or less collapsed, the tegmen being multiplicative with the outer epidermis as a palisade of malpighian cells, a reduced and nuclear endosperm, and a curved embryo. A comparative study of the seed development of $S$. cordifolia and S. veronicaefolia has been published (Rao 1955), and shows similarity to the three species of Sida.

Sida urens and S. rhombifolia present nonglandular trichomes on the hilum region and funiculus. According to Werker (1997), the seed trichomes are relatively uncommon on seeds and are characteristic of some families, such as Malvaceae, Apocynaceae (Asclepiadaceae) and Salicaceae. Corner (1976) asked whether the hairs of the outer exotesta are innovations on the seed, or inherited. It is possible this structural characteristic can aid in the phylogenetic study of the genus Sida.

The embryos of Sida belong clearly to the bent type, with folded cotyledons according to the Martin (1946) classification. The apical organization of the embryo radicle of Sida was found to be characterized by the presence of three layers of initials (Fig. 8f): one layer at the apex of the central cylinder; the second terminating the cortex; and the third originating at the epidermis and rootcap. Roots which have epidermis in common with the rootcap are frequent in eudicots (Evert 2006).

The occurrence of mucilage cavities is recorded in Malvaceae (Metcalfe \& Chalk 1950, Fahn 1979). In Sida species, the cavities were found to occur in the whole fruit. Different opinions exist over the manner of cavity development in Malvaceae, which are reported to develop schizogenously by some authors and lysigenously by others. The mucilage cavities of Sida were found to develop lysigenously by dissolution of mucilage and parenchymatous cells.

Structural features that are potentially significant in characterization of $S$. rhombifolia, S. regnellii and $S$. urens are the structure of the ovary, the morphology of the mericarp apex, the pattern of the reticulate sclerenchymatous endocarp, and the presence or absence of nonglandular trichomes in the hilum and funiculus of the seed.

\section{ACKNOWLEDGMENTS}

We thank CAPES ("Coordenação de Aperfeiçoamento de Pessoal de Nível Superior, Brasil") and CNPq ("Conselho Nacional de Desenvolvimento Científico e Tecnológico, Brasil") for the support granted to the accomplishment of this work.

\section{BIBLIOGRAPHY}

Barroso, G.M., M.P. Morim, A.L. Peixoto \& C.L.F. Ichaso. 1999. Frutos e Sementes: morfologia aplicada à sistemática de dicotiledôneas. Editora UFV, Viçosa. 441 pp.

Berlyn, G.P. \& J.P. Miksche. 1976. Botanical Microtechnique and Citochemistry. The Iowa State University Press, Ames, Iowa. $326 \mathrm{pp}$.

Corner, E.J.H. 1976. The Seeds of Dicotyledons. Volume 1. Cambridge University Press, Cambridge. 311 pp.

Esteves, G.L. 2004. Taxonomic characters of fruit and seed in brazilian species of Pavonia Cav. (Malvaceae). Hoehnea 31(1): 87-92.

Evert, R.F. 2006. Esau's Plant Anatomy - meristems, cells, and tissues of the plant body: their structure, function, and development. John Wiley \& Sons, Hoboken, New Jersey. $601 \mathrm{pp}$.

FAHN, A. 1979. Secretory Tissues in Plants. Academic Press, London. 302 pp.

FAHN, A. \& M. ZOHARY. 1955. On the pericarpial structure of the legumen, its evolution and relation to dehiscence. Phytomorphology 5: 99-111.

Guerrits, P.O. 1991. The Application of Glycol Methacrylate in Histotechnology; some fundamental principles. University Groningen, Netherlands. 326 pp.

Johansen, D.A. 1940. Plant Microtechnique. McGraw-Hill Book Company, New York. 523 pp.

Judd, W.S., C.S. Campbell, E.A. Kellogg, P.F. Stevens \& M.J. Donoghue. 2002. Plant Systematics; a phylogenetic approach. Sinauer Associates, Sunderland. $576 \mathrm{pp}$.

KARNOVSKY, M.J. 1965. A formaldehyde-glutaraldehyde fixative of high osmolality for use in electron microscopy. Journal of Cell Biology 27: 137-138.

KrapovicKas, A. 2006. Las especies argentinas y de países vecinos de Sida Secc. Nelavaga (Malvaceae, Malveae). Bonplandia 15: 5-45.

Martin, A.C. 1946. The comparative internal morphology of seeds. American Midland Naturalist 3: 513-660.

Metcalfe, C.R. \& L. Chalk. 1950. Anatomy of the Dicotyledons. Vol. I and II. Clarendon Press, Oxford. 1500 pp.

O'Brien, T.P., N. Feder \& M.E. McCully. 1964. Polychromatic staining of plant cell walls by toluidine blue O. Protoplasma 
59: $368-373$.

RaO, T.V.R. \& Y. DaVE. 2006. Histo-architecture of the pericarp and seed liberation in the schizocarpic fruit of Sida rhombifolia L. (Malvaceae). Pakistan Journal of Botany 38: 353-359.

Rao, T.V.R., Y.S. Dave \& J.A. Inamdar. 1986. Structure, ontogeny and morphology of glochid emergences on the fruit wall of Urena lobata L. (Malvaceae). Indian Botanical Contactor 2: 89-96.

RaO, T.V.R., Y.S. Dave \& J.A. Inamdar. 1993. Morpho-histogenic study of horned fruit of Pavonia sepium A.St. and its dehiscence. Phytomorphology 43: 1-8.

RaO, V.C. 1955. Embryological studies in Malvaceae 1 Fertilization and seed development. Indian National Science Academy 21: 53-67.

Rотн, I. 1977. Fruits of angiosperms. In Linsbauer, K., F.G. Tischler \& A. Pascher (eds.), Encyclopedia of Plant Anatomy, pp. 85-118. Gebrüder Borntraeger, Berlin.

Ruzin, S.E. 1999. Plant Microtechnique and Microscopy. Oxford University Press, New York. 322 pp.
Sass, J.E. 1951. Botanical Microtechnique. Iowa State College Press, Iowa. $227 \mathrm{pp}$.

SouzA, L.A. 2006. Fruto. In Souza, L.A. (org.), Anatomia do Fruto e da Semente, pp. 11-123. Editora Universidade Estadual de Ponta Grossa, Ponta Grossa.

Souza, A., K.S.M. Mourão \& L.A. SouZA. 2005. Morfologia e anatomia do fruto e da semente em desenvolvimento de Pilocarpus pennatifolius Lem. (Rutaceae). Revista Brasileira de Botânica 28: 745-754.

Souza, L.A., S.M. Rosa \& I.S. Moscheta. 2006. Anatomy of the developing fruit of Metrodorea nigra A. St.-Hil. (Rutaceae). Brazilian Archives of Biology and Technology 51: 1171-1179.

SpJut, R.W. 1994. A systematic treatment of fruit types. Memoirs of New York Botanical Garden 70: 1-182.

Werker, E. 1997. Seed anatomy. In: S. Carlquist (ed.), Encyclopedia of Plant Anatomy, pp. 54-65. Gebrüder Borntraeger, Berlin.

WiLlis, J.C. 1973. A Dictionary of the Flowering Plants and Ferns. At the University Press, Cambridge. 1214 pp.

Recibido: 28.05 .12

Aceptado: 26.11.12 